$\mathrm{DOI}$

\title{
КОМБІНОВАНЕ ЛІКУВАННЯ ДИСЦИРКУЛЯТОРНОї ЕНЦЕФАЛОПАТІї: ГІРУДОТЕРАПІЯ В ПОЄДНАННІ З НУТРИЦІОЛОГІЧНИМИ МЕТОДАМИ
}

\author{
๑А. Й. Лабінський \\ Львівський національний медичний університет ім. Данила Галицького
}

РЕЗЮМЕ. У роботі вивчено вплив гірудотерапії в поєднанні з нутриціологічною корекцією на хворих $з$ дисциркуляторними енцефалопатіями. Ці методи у вказаних хворих покращують об'єктивний стан та сприяють відновленню в тканинах полярних ліпідів та етерифікованого холестерину, який $є$ основною складовою клітинних і судинних мембран, що дало можливість підвищити ефективність немедикаментозного лікування та покращити якість життя пацієнтів з ДЕ ІІ ст.

КЛЮчОВІ СлОВА: дисциркуляторна енцефалопатія, гірудотерапія, нутриціологічна корекція.

Вступ. Судинні захворювання головного мозку, до яких належить дисциркуляторна енцефалопатія (ДЕ), є однією зі складних медичних проблем. В Україні постійно збільшується відсоток хворих на цю хворобу, змінюється специфіка їі клінічних проявів, особливо у працездатного населення. Доведено, що найважливішим чинником розвитку ДЕ $\epsilon$ підвищений рівень холестеролу, що призводить до прогресування захворювання. Згідно з сучасними уявленнями про роль ліпідного обміну в патогенезі ДЕ, профілактика та лікування цієї хвороби шляхом використання фармакологічних препаратів, які знижують рівень холестеролу, тригліцеридів та ліпопротеїнів у крові, довели, що вони мають лише тимчасовий ефект, який діє на час прийому ліків. Сьогодні не існує надійних лікарських засобів, які 6 збільшували рівень антиатерогенних ліпопротеїнів високої щільності, що змогло 6 забезпечити ефективність лікування дисциркуляторної енцефалопатії [3]. Тому не дивлячись на появу нових методів лікування за допомогою нових лікарських засобів, проблема залишається досить актуальною [1].

Вищенаведене свідчить про необхідність запровадження комплексного лікувально-діагностичного алгоритму ведення пацієнтів з порушенням мозкового кровообігу з використанням немедикаментозного лікування [5].

Мета дослідження. Оцінити інноваційний комплекс лікувально-діагностичного алгоритму для лікування дисциркуляторної енцефалопатії II ст. з використанням гірудотерапії в поєднанні з нутриціологічними методами.

Матеріал і методи дослідження. Сьогодні медикаментозна терапія судинних порушень не вирішує основного питання - зниження росту цієї захворюваності. Така терапія передбачає застосування гепарину або подібних препаратів, що, незважаючи на спеціальні схеми введення, все ж таки часто призводить до розвитку прогресуючої тромбоцитопенії зі всіма її грізними для життя наслідками та вимагає постійного динамічного контролю за вмістом тромбоцитів крові.

Тому нами для виконання поставленої мети обстежено та проліковано 57 хворих (чоловіки та жінки) у віці від 45 до 65 років з дисциркуляторною енцефалопатією II ст., які в своєму анамнезі мали супутню патологію (артеріальну кардіальну гіпертензією II ст. і загальний та церебральний атеро-артеріосклероз). Хворі перебували на амбулаторному лікуванні в 4-й комунальній поліклініці м. Львова (неврологічному, терапевтичному денному стаціонарі). Діагноз встановлювали на підставі скарг, анамнестичних даних, об'єктивного неврологічного статусу, доплерографії судин шиї і нижніх кінцівок, даних комп'ютерної рентгенівської та магнітно-резонансної томографії, загальноприйнятих лабораторних методик. Магнітнорезонансну томографію (МРТ) проводили на томографі «Образ», комп'ютерну томографію (КТ) проводили на обчислювальному рентгенівському томографі СРТ 1010. Це дослідження дало можливість визначити прижиттєво морфологічні зміни речовини головного мозку у хворих на дисциркуляторну енцефалопатію.

Томографічний аналіз включав загальну візуальну оцінку та кількісні показники. Враховували розміри, кількість і локалізацію вогнищ зниженої щільності, дифузне зниження щільності (лейкоареозис), а також розміри шлуночкової системи та субарахноїдальних просторів.

Дослідження стану церебральної та периферійної гемодинаміки судин шиї і нижніх кінцівок проводили за допомогою ультразвукового сканера ULTIMA Рго30 (Україна, РАДМІР). При дослідженні артерій оцінювали: анатомічну (структурну) характеристику ходу артерій, яка включала стан просвіту артерій, стінки артерій, характеристику внутрішньопросвітних і пристінкових патологічних нашарувань; гемодинамічну характеристику, що відображає характер та спектр кровообігу, кольорове доплерівське картування, 
Огляди літератури, оригінальні дослідження, погляд на проблему

направлене енергетичне картування, яке проводилося для пошуку ділянок з аномальним кровообігом, кількісну характеристику кровообігу. Всі швидкісні параметри кровообігу для кожної артерії вимірювалися в режимі автоматичної оцінки параметрів кровообігу, усередненої за трьома серцевими циклами.

Особливим і важливим було біохімічне дослідження показників ліпідного гомеостазу волосся та волосяних фолікул хворих на дисциркуляторні енцефалопатії, яке проводили хворим до і після лікування для визначення полярних ліпідів, ефірів холестерину, вільних жирних кислот, триацилгліцеринів та вільного холестерину [6].

Усі хворі отримували по пять сеансів гірудотерапії. Під час лікування відміняли будь-яке медикаментозне лікування. П'явки прикладали в зони заокципітальної ділянки, верхні поля Кренінга, зону Щербакова, шийний відділ хребта. Застосовували методику прикладання п'явок 3 повним крововідбором. Сеанси проводили 1 раз у п'ять днів. Під час першого сеансу прикладали дві п'явки паравертебрально на рівні сьомого шийного хребця і ще дві п'явки паравертебрально на рівні першого куприкового хребця. Під час другого сеансу прикладали по одній п'явці в точки проекції шилососкоподібних отворів на шийно-потиличній ділянці, одну - між остистими паростками другого і третього шийних хребців та одну - між остистими паростками четвертого та п'ятого шийних хребців. Під час третього сеансу прикладали дві п'явки на заокципітальні ділянки та по одній п'явці на проекцію жовчного міхура та головки підшлункової залози, враховуючи їх роль в метаболізмі ліпідів та виникненні ДЕ ІІ ст. Під час четвертого сеансу прикладали п'явки по одній між остистими відростками третього та четвертого шийних хребців і ще дві паравертебрально в ділянці першого-другого грудних хребців, враховуючи вихід в цій ділянці нерва, який регулює серцеву діяльність. П'ятий сеанс - дві п'явки повторно в проекцію шилососкоподібних отворів на шийно-потиличній ділянці та одну п'явку в проекції першого шийного хребця і foramen magnum посередині.

За декілька днів до початку сеансів гірудотерапії хворих переводили на спосіб харчування за принципами інноваційної технології [5]. Вилучали з харчування тваринні жири, окрім риб'ячого, бульйони, відвари, смажені страви і солодкі кондитерські вироби, в яких містяться трансатерогенні жири. В раціон додавали квітковий пилок та мед по десертній ложці їх суміші двічі на день, перед сніданком та обідом. Індивідуально для кожного пацієнта в залежності від змін добових і психологічних біоритмів призначали режим хар- чування, який передбачав прийом їжі тільки при настанні стійкого відчуття голоду. Достатню кількість антиоксидантних та баластних речовин забезпечували підвищеним вмістом (до двох кілограм) в раціоні фруктів та фрешів (яблук 3-5 штук, ківі 2-3 шт., гарбузовий та моркв'яний фреші по 1 склянці).

Результати й обговорення. У результаті клініко-неврологічного обстеження хворих на початку дослідження привертала увагу різноманітність суб'єктивної симптоматики. Більшість клінічних симптомів були характерними для всіх обстежених пацієнтів з ДЕ ІІ ст. Це головний біль (89 \%), запаморочення (90\%), шум в голові (як періодичний, так і постійний), хиткість при ході, слабкість в нижніх кінцівках, оніміння дистальних відділів кінцівок, порушення сну, загальна слабкість, швидка стомлюваність, зниження фону настрою, зниження пам'яті, різноманітні погіршення стану пароксизмального характеру. За нашими даними, у 85 \% пацієнтів був присутній постійний головний біль, який часто мав комбінований характер (судинна та лікворна дисфункція), при виникненні запаморочення відзначався шум, дзвін в голові або вухах, нудота, відчуття закладеності вух. У хворих спостерігалася хиткість, невпевненість при ході; слабкість, тяжкість в нижніх кінцівках; дифузні болі в дистальних відділах нижніх кінцівок.

Після запропонованого лікування, за даними доплерівського обстеження, кількість ділянок 3 аномальним кровообігом виявлена у 22 \% пацієнтів. Усі швидкісні параметри кровообігу для кожної артерії покращились в середньому на $17 \%$. За даними томографічного аналізу спостерігали зменшення розмірів та кількості вогнищ зниженої щільності. Біохімічні хроматографічні визначення ліпідів у тканинах хворих до- і після проведеного лікування зафіксували значні позитивні зміни у всіх їх фракціях (табл. 1).

Полярні ліпіди, як видно з таблиці 1, при ДЕ у волоссі хворих до лікування складали в середньому 0,13 ммоль/л. Після проведеного немедикаментозного лікування значення вказаної фракції ліпідів склало 0,16 ммоль/л, що є статистично вірогідним збільшення кількості полярних ліпідів у волоссі групи хворих з дисциркуляторною енцефалопатією.

Для даної варіаційної сукупності коефіцієнт кореляції дорівнює 0,6, що свідчить про достатню однонаправленість даних у статистичній вибірці.

Кількість ефірів холестерину у волоссі хворих на дисциркуляторну енцефалопатію, порівняно з полярними ліпідами, $є$ більшим і складає 0,16 ммоль/л. Після проведеного немедикантозного лікування значення вказаної фракції ліпідів 
Огляди літератури, оригінальні дослідження, погляд на проблему

Таблиця 1. Динаміка біохімічних змін у тканинах хворих до- і після лікування

\begin{tabular}{|c|c|c|c|c|c|c|}
\hline \multicolumn{2}{|c|}{$\begin{array}{c}\text { Фракції ліпідів } \\
\text { до і після лікування }\end{array}$} & Кількість & $\mathrm{y}_{\mathrm{KB}}$ & $\begin{array}{c}\text { р (коефіцієнт } \\
\text { достовірності) }\end{array}$ & $\begin{array}{l}\text { t (коефіцієнт } \\
\text { Стюдента) }\end{array}$ & $\begin{array}{l}\text { Коефіцієнт } \\
\text { кореляції }\end{array}$ \\
\hline \multirow[t]{2}{*}{ Полярні ліпіди } & до лікування & $0,13 \pm 0,005$ & 0,0016 & \multirow[t]{2}{*}{$<0,05$} & \multirow[t]{2}{*}{2,85} & \multirow[t]{2}{*}{0,60} \\
\hline & після лікування & $0,16 \pm 0,006$ & 0,0021 & & & \\
\hline \multirow{2}{*}{$\begin{array}{l}\text { Ефіри холе- } \\
\text { стерину }\end{array}$} & до лікування & $0,20 \pm 0,005$ & 0,0015 & \multirow[t]{2}{*}{$\geq 0,05$} & \multirow[t]{2}{*}{1,37} & \multirow[t]{2}{*}{0,63} \\
\hline & після лікування & $0,21 \pm 0,006$ & 0,0022 & & & \\
\hline \multirow{2}{*}{$\begin{array}{l}\text { Вільні жирні } \\
\text { кислоти }\end{array}$} & до лікування & $0,22 \pm 0,006$ & 0,0019 & \multirow[t]{2}{*}{$\geq 0,05$} & \multirow[t]{2}{*}{$-0,85$} & \multirow[t]{2}{*}{0,51} \\
\hline & після лікування & $0,21 \pm 0,006$ & 0,0021 & & & \\
\hline \multirow{2}{*}{$\begin{array}{l}\text { Триацил } \\
\text { гліцерини }\end{array}$} & до лікування & $0,21 \pm 0,006$ & 0,0019 & \multirow[t]{2}{*}{$<0,05$} & \multirow[t]{2}{*}{$-2,94$} & \multirow[t]{2}{*}{0,56} \\
\hline & після лікування & $0,18 \pm 0,007$ & 0,0028 & & & \\
\hline \multirow{2}{*}{$\begin{array}{c}\text { Вільний } \\
\text { холестерин }\end{array}$} & до лікування & $0,37 \pm 0,09$ & 0,0046 & \multirow[t]{2}{*}{$<0,05$} & \multirow[t]{2}{*}{$-2,65$} & \multirow[t]{2}{*}{0,76} \\
\hline & після лікування & $0,33 \pm 0,08$ & 0,0038 & & & \\
\hline
\end{tabular}

зросло, хоч і менш виражено. Для даної варіаційної сукупності коефіцієнт Стьюдента дорівнює 1,37, що не підтверджує достатню статистичну вірогідність збільшення кількості ефірів холестерину у волоссі групи хворих з дисциркуляторною енцефалопатією. Вільні жирні кислоти при дисциркуляторних енцефалопатіях зазнали дуже незначних змін. До лікування їх кількість у тканинах волосяних фолікул та волосся складала 0,22 ммоль/л. Після проведеного немедикаментозного лікування їх вміст у вказаних тканинах становив 0,21 ммоль/л. При проведенні статистичного варіаційного аналізу для вказаної групи хворих коефіцієнт Ст'юдента був 0,85. Такий незначний ріст не $\epsilon$ статистично достовірним $(P \geq 0,05)$. При проведенні кореляційного аналізу виявлялись різнонаправлені зміни у більшій половині досліджуваних випадків і, відповідно, значення коефіцієнта кореляції склало 0,51.

Триацилгліцерини при ДЕ зазнали вже більш значних змін (рис. 1). До лікування їх кількість у тканинах волосяних фолікул та волосся складала 0,21 ммоль/л. Після проведеного немедикаментозного лікування їх вміст у вказаних тканинах складав 0,18 ммоль/л. При проведенні статистичного варіаційного аналізу для вказаної групи хворих коефіцієнт Стьюдента був 0,85. Такий достатньо значний ріст $\epsilon$ статистично достовірним $(P<0,05)$. При проведенні кореляційного аналізу виявлялись більш однонаправлені зміни дещо більше, ніж у половині досліджуваних випадків. Значення коефіцієнта кореляції склало 0,56.

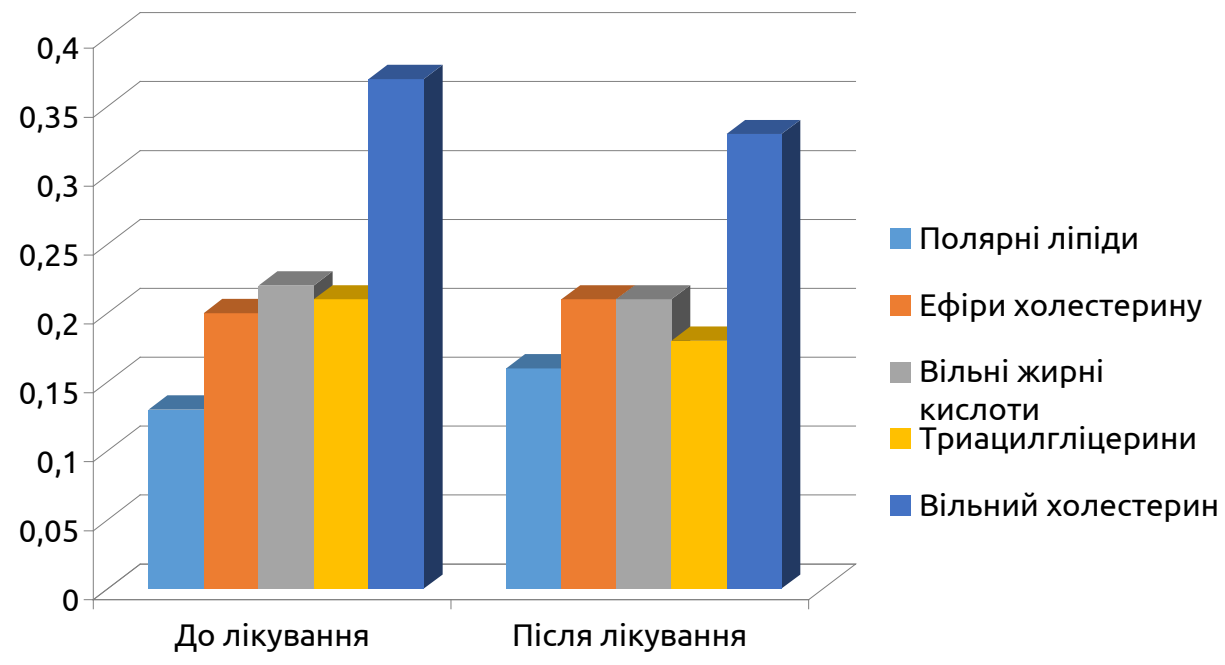

Рис. 1. Розподіл хворих до та після лікування.

Вільний холестерин при дисциркуляторній енцефалопатії, як видно із рисунка 1, у волоссі хворих до лікування складав 0,37 ммоль/л. Після проведеного немедикантозного лікування значення вказа- ної фракції ліпідів знизилось на 0,04 ммоль/л. Для даної варіаційної сукупності коефіцієнт Стьюдента дорівнює 2,8, що підтверджує статистичну вірогідність зниження кількості вільного холестерину у 
Огляди літератури, оригінальні дослідження, погляд на проблему

волоссі хворих з ДЕ. При проведенні кореляційного аналізу між групами хворих до та після лікування відмічається високий ступінь однонаправленості змін. Коефіцієнт кореляції складає 0,76, що є найвищим, порівняно з показниками змін інших фракцій ліпідів після проведеного лікування.

В патогенезі судинно-гематологічних змін при ДЕ центральне місце займають утворення в судинному руслі тромбіну і виснаження механізмів, що запобігаютъ згортанню крові та агрегації тромбоцитів [6]. Утворення у вогнищі ішемічного пошкодження вазоактивних речовин (тромбін, серотонін, аденозинтрифосфат, катехоламіни), а також зниження синтезу простацикліну провокують агрегацію тромбоцитів і призводять до розвитку енцефалопатії [5].

Сучасні антикоагулянтні лікарські засоби впливають неоднозначно на всі описані вище ланки патогенезу, викликаючи кровотечі та інші побічні явища. При застосуванні інноваційного комбінованого лікування ми бачимо достатньо значне регресування симптомів захворювання не тільки за даними об'єктивного обстеження, але й за даними доплерографії та томографічної картини. Особливо наочними $\epsilon$ результати біохімічних досліджень. Те, що триацилгліцерини і вільний холестерин, які $\epsilon$ основними атерогенними чинниками із всіх фракцій ліпідів при ДЕ, зазнали значних змін в сторону зменшення, свід-

\section{ЛІТЕРАТУРА}

1. Волошин П. В. Аналіз поширеності та захворюваності на нервові хвороби в Україні / П. В. Волошин, Т. С. Міщенко, $Є$. В. Лекомцева // Международный неврологический журнал. - 2006. - № 3. - С. 9-13.

2. Спосіб підвищення ефективності лікування дисциркуляторних енцефалопатій атеросклеротичного ґенезу / М. М. Гуйтур, О. А. Козьолкін, Н. М. Гуйтур [та ін.] // Кардіальний, церебральний та периферійний атеросклероз. Актуальні питання діагностики та лікування : матер. наук.-практ. конф. молодих вчених із міжнародною участю. - Івано-Франківськ, 15-16 травня 2003 p. - C. 57-58.

3. Міщенко Т. С. Особливості клініко-неврологічних порушень та добовий профіль артеріального тиску у хворих на судинну деменцію, обумовлену артеріальною гіпертензією / Т. С. Міщенко, О.В.Дмитрієва, чить про антиатерогенний вплив комбінованого лікування. Ріст кількості фракцій полярних ліпідів при використанні гірудотерапії в комплексі з нутриціологічною корекцією вказує на можливість відновлення ліпідного балансу, а значить на можливість призупиняти розвиток дисциркуляторних змін при енцефалопатії.

Висновки. Зниження кількості холестерину низької щільності на 10 \% та достовірне збільшення кількості полярних ліпідів на 22 \% при визначенні кількості різних фракцій ліпідів у волоссі хворих ДЕ до лікування і після зазначеної вище немедикаментозної терапії однозначно свідчить про регресію патологічних змін ліпідного балансу в тканинах хворих з досліджуваною патологією.

Ефективність застосування гірудотерапії в поєднанні з нутриціологічною корекцією $\epsilon$ очевидною за даними об'єктивного та додаткових обстежень.

Аналізуючи результати досліджень ми виявили, що вплив секрету алотрофічних залоз п'явок медичних $\epsilon$ ефективним в поєднанні з нутриціологічними методами для лікування дисциркуляторної енцефалопатії і не викликає побічних наслідків.

Перспективи подальших досліджень. Пошук інших ефективних шляхів реабілітації пацієнтів 3 дисциркуляторною енцефалопатією.

Т. Г. Перцева // Когнітивні порушення при старінні : матер. наук.-практ. конф. - Київ, 2007. - С. 45-46.

4. Міщенко Т. С. Прогностичні можливості Фрамінгемської шкали щодо цереброваскулярних подій у мешканців Північного Сходу України / Т. С. Міщенко, Г.В.Лінська // Український вісник психоневрології. 2013. - Т. 21, Вип. 4. - С. 77.

5. Лабінський А. Й. Лікування судинних захворювань бджолами, п'явками та дієтою. Апітерапія, грудотерапія, нутріціологія / А. Й. Лабінський. -Аверс : Львів, 2014. - 102 c.

6. Клініко-біохімічне дослідження хворих з транзиторними ішемічними атаками при гірудотерапії / А. Й. Лабінський // Експериментальна та клінічна фізіологія і біохімія. - 2012. - № 1. - С. 101-104.

\section{COMBINED TREATMENT OF DYSCIRCULATORY ENTSEFALOPATHY: HIRUDOTHERAPY IN COMBINATION WITH NUTRIOCIOLOGICAL APPROACHES}

๑A. Y. Labinskyi

\section{Lviv National Medical University by Danylo Halytskyi}

SUMMARY. In this paper we studied the effect of hirudotherapy in combination with nutriocyological correction in patients with dyscirculatory entsefalopathy. It is shown that in a complex with hirudotherapy nutriocyological correction, restores the lipid balance of tissues, normal permeability of cell membranes and vascular increase the efficiency of drugfree treatment of cerebrovascular disease.

KEY WORDS: dyscirculatory entsefalopathy, hirudotherapy, nutriociological correction. 